\title{
Wear resistance of self-lubricating coatings due to the formation of carbide graphite
}

\author{
V. P. Babak • V. V. Shchepetov • S. D. Kharchenko \\ Institute of Engineering Thermophysics, National Academy of Sciences of Ukraine, Kyiv, Ukraine
}

Received: 10 March 2020 / Accepted: 25 May 2020

\begin{abstract}
The results of researching the characteristics of friction and wear of the developed self-lubricating nanocomposite coatings containing $\mathrm{MgC}_{2}$, are presented. Due to the interrelation of thermal and mechanical fluctuations, magnesium carbide thermally decomposes and forms structurally free $\alpha$-graphite. The specified graphite creates a surface antifriction layer, which minimizes the contact parameters. The composition and structure of self-lubricating coatings are proposed, which showed high wear-resistant properties in the entire load-speed range, simulating the operation of the friction unit in field operating condition. It is shown that the means of controlling wear and ensuring high performance is the presence of both a thin film layer of graphite and the formation of fine secondary structures. All this provides the modification of the friction surface and protects unacceptable plastic deformation processes.
\end{abstract}

Keywords: friction, wear, secondary structures, anti-friction layer.

\section{Introduction}

Friction is associated with one of the most pressing problems of modern technology - the wear of machinery. Wear, as a universal phenomenon of degradation of materials during friction, limits the possibilities and reduces the life of technical systems. Thus, studies that reduce friction and increase wear resistance are necessary and important.

The reliability of tribological couplings depends not only on a rational choice of pair materials, but also significantly on the type of lubricant that ensures the stability of the set properties over time.

The increasing complexity of operating conditions that arise with the improvement of tribotechnical systems make technical and operational limitations for the use of traditional liquid and greases. Thus, there is a need to use solid process lubricants. These lubricants reflect the commonness of processes under the conditions of one phenomenon and, together with traditional lubricants, support tribological properties. Difficulties are in finding the most effective ways of introducing solid lubricants into the contact zone [1-4].

Depending on the design of the mating parts, load-speed and temperature conditions, as well as the technological resource, graphite-based solid lubricants are used in the form of dry powder lubricants, briquettes or pencils, suspensions, mixtures of solid compositions and binders from various resins. Solid lubricants are also used in combined anti-friction surface layers. There are attempts to use plasma spraying for applying solid lubricant particles to a directed flow of dispersed particles of a sprayed material $[5,6]$. There are technological difficulties, graphite, depending on the spraying temperature, forms a chemical compound, burns out or sublimates.

There are positive results in achieving the quality of antifriction materials through the use of solid lubricants, but theoretical and applied problems of friction, wear and lubrication of machines remain the most complex scientific and technical problems that have to be solved when operating modern equipment. The persistent need, caused by production goals and the intrinsic logic of scientific development, requires new solutions in the study of the universal metallurgical imperative, which determines the interdependence of the chemical composition, its formation structure with the

V. P. Babak

vdoe@ukr.net

\section{V. Shchepetov}

vvs2020@ukr.net
S. D. Kharchenko

nanoavia@ukr.net 
formation technology and functional properties of solid lubricated materials $[7,8]$. The development of science depends not only on the emergence of new ideas, but also on the implementation of their results.

The most intensively developing cognitive direction in modern tribotechnology is the search for applied solutions to the formation of nanostructured compositions. Since the overdispersed structure is the cause of a significant increase, and in some cases, a radical change in the operational properties.

Summarizing the above, it can be noted that the development of powder compositions for detonation spraying of antifriction self-lubricating nanostructured coatings for operation in extreme conditions is one of the priority areas of modern tribotechnical materials science and an important task of extending the service life of machine parts.

The aim of the work is to study, within the framework of the phenomenological approach, the wear resistance of detonation nanostructured composite self-lubricating coatings and to establish the effect of carbide graphite, which is formed under increased loads under thermodynamic effects, on their surface properties.

\section{Materials and research methods}

For detonation spraying of antifriction coatings ( $\left.\mathrm{Cr}-\mathrm{Si}-\mathrm{B}-\mathrm{MgC}_{2}\right)$, nanostructured composite powders were used. When they were obtained under conditions of high-energy mechanochemical synthesis, to eliminate the adhesion of the powder to the chamber walls and to optimize the process of spheroization of the components in a homogeneous mixture, ultrasound was used [9].

To analyze the friction surface, a "Camscan-4DW" scanning electron microscope and microanalyzer and the «Lanscan» software program were used, along with the distribution of chemical elements along the scanning line. Also, at each point with an electronic probe $(d=1.5 \mu \mathrm{m})$, a qualitative chemical analysis was carried out with the subsequent construction of a distribution line.

To determine the phase composition of the surface layers, we used a DRON-3 X-ray diffractometer to take the Cr-radiation diagram (BSV-22 tube) without a monochromatograph.

The studied coatings were sprayed according to the developed method using two dosers. The first was filled with a Cr-Si-B nanostructured powder composition; the second was loaded with $\mathrm{MgC}_{2}$ powder. The first dispenser was turned on and a layer of nanostructured composition was sprayed. Then together included two dosers. The coating thickness after finishing was $0,30-0,35 \mathrm{~mm}$ at $R_{a} \approx 0,63-0,32$.

The antifriction properties of the coatings were determined by friction of the ring samples (end-to-end scheme) under distributed contact conditions at a sliding speed of $0.8 \mathrm{~m} / \mathrm{s}$. The load ranges during testing are most approximated to the processes of physical and chemical mechanics of friction and wear, to the real conditions of frictional contact.

The research program for nanoscale coatings compares their wear resistance with those obtained under the same test conditions for tungsten-containing coatings of the VK type and coatings of doped nichrome powder.

\section{Research results and discussion}

The main factors that determine the essential properties and mechanisms of the friction processes are external influences. They, ordered by a causality, determine the ratio and gradients of elastoplastic deformation, the thermodynamic state, the ratio of activation, fluctuations, and determine the leading type of wear.

Based on the test results of the coatings under study, averaged graphs of wear intensity and friction coefficients were constructed as a function of load at a constant sliding speed of $0.8 \mathrm{~m} / \mathrm{s}$.

Nanocomposite coatings have the greatest wear resistance during a monotonely increase in load (curve 1 and 1'). For them, minimum wear rates are nearly constant across the entire test range.

A study of the initial state and structure of the nanocoating made it possible to establish that the lamella shape and multiphase are typical for them. In this case, the nanocoating strongly adheres to the matrix, copying the surface texture. A metallographic analysis of the crosscut end of the sprayed layer did not reveal any contamination on the deformable particles. In addition, defects in the form of pores, cavities, and cracks were also not detected.

The nature of the interaction of the coating components was studied using the "Lanscan" program. It was established that the spectra of the distribution of chromium along the scanning line coincide with the phases of silicon and boron. This confirms their interaction and the production of chromium carbide, chromium silicide, as well as the possibility of the formation of ternary compounds.

An analysis of the lines and scans of oxygen with the elements that make up the coating showed their complete phase alignment. This indicates their chemical interaction, which causes surface passivation due to the formation of oxide secondary structures. The results of microroentgen spectral and X-ray phase analysis of the $\mathrm{Cr}-\mathrm{Si}-\mathrm{B}-\mathrm{MgC}_{2}$ coating allowed us to classify their structure as a thin conglomerate (up to $80 \%$ of the volume). It consists of boronsaturated ultrafine inclusions with an average size of 6-10 nm (such as $\mathrm{Cr}_{5} \mathrm{~B}_{3}, \mathrm{CrB}, \mathrm{Cr}_{3} \mathrm{~B}_{4}, \mathrm{CrB}_{2}$ ). The structure of the inclusions is determined by boron atoms forming rigid sublattices with $\mathrm{Cr}-\mathrm{Si}-\mathrm{B}$ bonds. A solid solution based on the 
$\beta$-B rhombohedral lattice was also detected. A boride phase of the $(\mathrm{Cr}, \mathrm{Si})_{4} \mathrm{~B}_{5}$ type was discovered, which has uniform grains, chromium borosilicide $\left(\mathrm{Cr}_{2} \mathrm{~B}_{2} \mathrm{Si}\right)$, intermetallic particles of silicides such as $\mathrm{CrSi}, \mathrm{CrSi}_{2}, \mathrm{CrSi}_{3}$, as well as silicon borides $\mathrm{SiB}_{5}, \mathrm{SiB}_{6}$, in a viscous two-phase chromium-boron-silicon matrix.

The tribotechnical properties of the coating form the structure and phase composition, as well as the quality of the surface films that form during friction. The study of the composition and properties of surface films is the main subject of physicochemical analysis and has important applied and scientific importance for the stability of normal mechanochemical processes.

To obtain complete information in the study of thin surface layers in which structural-thermal activation processes occur, the secondary-ion mass spectroscopy (SIMS) method was also used. This method allowed us to analyze the change in the microstructure in thin surface layers, to find the nature of the phases, their crystal structure and unit cell parameters, which are necessary to identify the phases and composition within homogeneous areas.

The results obtained allow us to conclude that the surface films of the initial coatings, which screen the adhesive interaction in the friction contact, have a finely dispersed structure and consist of a mixture of the phases of the composite coating and the products of their interaction with atmospheric oxygen. By stoichiometric, they are a complex, difficult to activate complex in the form of a finely dispersed mixture of $\mathrm{Cr}_{2} \mathrm{O}_{3}, \mathrm{SiO}_{2}, \mathrm{MgO}, \mathrm{B}_{2} \mathrm{O}_{3}$ and complex phases such as $\mathrm{CrSi}_{2} \mathrm{O}_{4}$ silicides and $\mathrm{SiCrO}_{2}$ chromates. This mixture, under conditions of contact pressures and temperatures, which is the cause of mechanochemical alloying, forms thin-film heterogeneous heat-resistant surface structures. In addition, the concentration maxima of the $\mathrm{X}$-ray spectra indicate the probability of the existence of solid solutions of the $\mathrm{Cr}_{2} \mathrm{O}_{3}-\mathrm{SiO}_{2}$ and $\mathrm{Cr}_{2} \mathrm{O}_{3}-\mathrm{B}_{2} \mathrm{O}_{3}$ types. The presence of a thermally stable boric anhydride changes chromium oxide into a metabolite of the $\mathrm{Cr}_{2}\left(\mathrm{BO}_{2}\right)_{2}$ type. Boric anhydride is formed by the interaction of higher chromium borides and environmental oxygen and is a chemically active form of boric acid. In fact, these are mesoscopic heterogeneous oxide pattern that have a translational crystallographic structure.

In accordance with the first law of thermodynamics, the friction work, which is the source of activation, is mainly used to generate heat and is partially accumulated by the material of friction pairs.

According to the structural energy concept proposed by B.I. Kostetskiy, the component of the work of external friction, which is used to generate heat, under normal conditions of contact interaction will be from 70 to $99 \%$. The rest of the work of external friction is used to change the internal energy of the surface layers. The energy that is accumulated by the friction surface is concentrated, as is known, in the thinnest surface layer. The effective volume of this layer has a depth of tens to hundreds of nanometers. A change in the energy density in a local microvolume under friction loading tends to a critical value that the activated surface layer can accumulate before destruction.

The energy value of the specific work of wear, which was obtained at the initial moment of testing during running-in, amounted to about $10^{4} \mathrm{~kJ} / \mathrm{mm}^{3}$. This was ample to provide the conditions of thermal solid - phase decomposition of magnesium carbide, which was in the coating, and the formation of structurally free $\alpha$-graphite. The particle shape of the graphite structure is similar to a scaly one, consisting of randomly arranged polydisperse crystallites, including up to 4 planar atomic lattices. The distance between the planes with a reasonable probability is about $0.6 \mathrm{~nm}$.

It is established that the basis of physical phenomena that determine the decomposition mechanism of carbide graphite is the processes of structural transformations in the solid phase, which develop as a result of thermal effects. The main factors that determine the threshold values of the thermodynamic processes of graphitization are the dispersion of the material, temperature, the presence of initiating elements - carbon, silicon, magnesium, and others. In addition, environmental properties and external influences, in particular, the load, are of great importance.

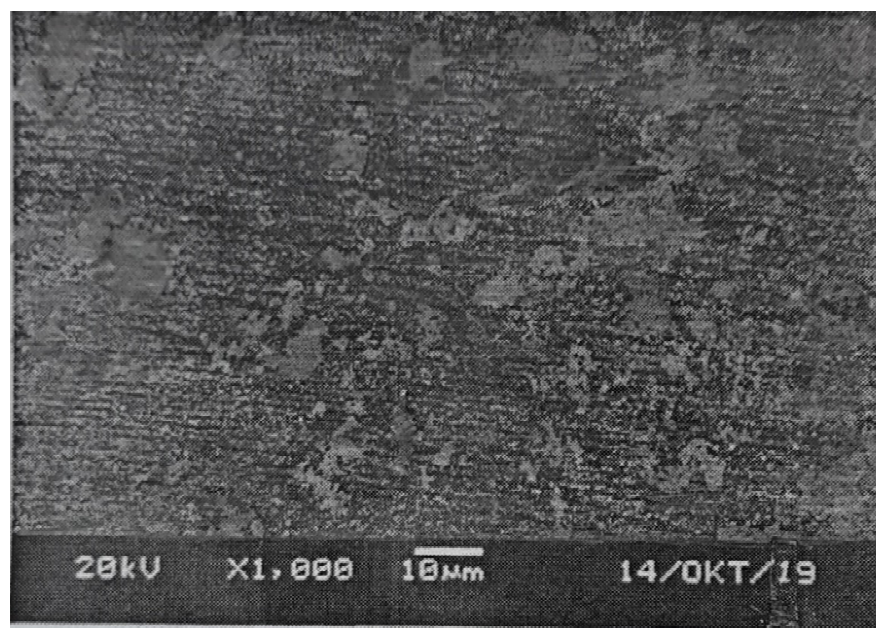

Fig. 1. Microphotography of the friction surface of the coated sample $\mathrm{Cr}-\mathrm{Si}-\mathrm{B}-\mathrm{MgC}_{2}$ 
The elementary act of the high-temperature reaction in the unit volume of the local area of the contact of the friction pair, which forms carbide $\alpha$-graphite, has the ability, due to the exothermic process, to cause the next elementary act, thus causing the potential for self-propagation. In the microphotograph (Fig. 1) of the sample tested at a load of $5 \mathrm{MPa}$, the antifriction film of graphite covers almost the entire friction surface. This provides an increase in the real contact area and reduces the specific load due to an increase in the reference length of the profile due to the filling and alignment of surface microroughnesses, microcracks, and fixing of the microparticles of the graphite layer in the microdimples of contact pairs.

The contact zone, which adjoins the friction surface and separates the coating material from the antifriction film (polydisperse particles of graphite), represents the thinnest plastic deformable layer. This layer, according to the micro $\mathrm{X}$-ray spectral analysis (MAR-3, probe diameter $1 \mu \mathrm{m}$ ), is a conglomerate of dispersed phases, mainly silicides, borides and solid solutions, which are very difficult to determine exactly.

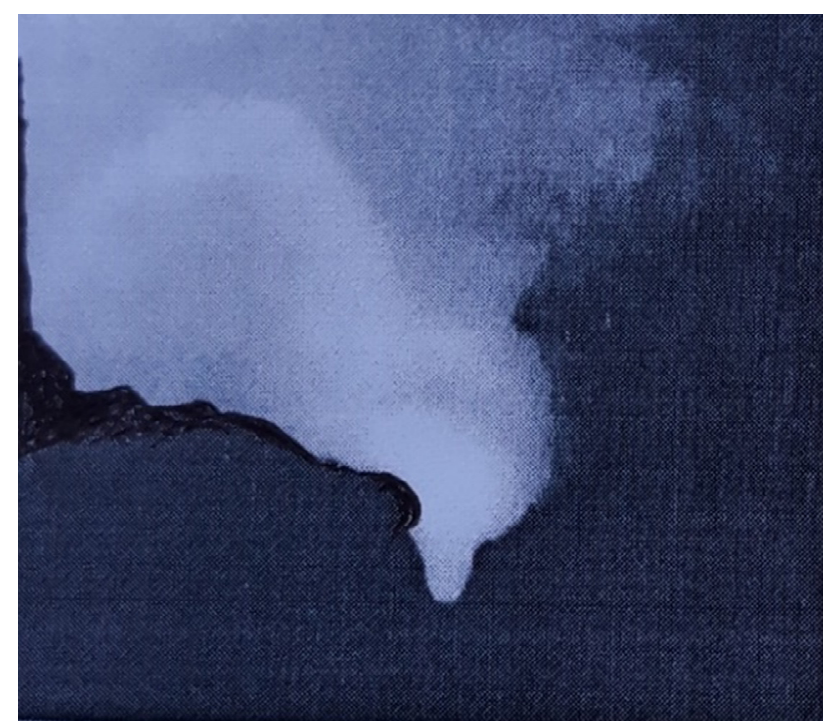

Fig. 2. Electron diffraction pattern from the surface of the contact layer, $P=5.0 \mathrm{MPa}(\mathrm{EM}-4$, shooting for reflection, $U=35 \mathrm{kV}$ )
Fig. 2 shows the electron diffraction pattern from the surface of the contact layer.

Diffusion halos with textured maxima, according to modern ideas about the nature of the ultrafine state $[10,11]$, proves that its structure corresponds to an ultrafine structure with directional orientation in the friction zone. According to the authors, the reason for the formation of such a structure is the tribomechanical interaction of contact surfaces at high specific pressures and temperatures, sudden cooling, and general compaction. This gives during friction a consolidation of the composition into a complexly alloyed layer of highly dispersed structures, which are similar in structurei to dispersion-strengthened materials. It should be noted that as a result of the interaction of friction-activated surface components with environmental elements (passivators), a complex of secondary structures of type 2 is formed. Thus, magnesium has the properties of a deoxidizer and effectively forms high-temperature oxides. Also, the active components of the coating, which form stable chemical compounds with oxygen, are chromium, silicon and boron. In this case, silicon dioxide is located in the inner layers of the oxides, near the edge of the surface. According to the authors, this is due to the increased energy of formation and provides counted anti-wear properties, and in the outer layer is in contact with the atmosphere. A decrease in the period of the crystal lattice of chromium is noted, which proves the formation of solid solutions of the introduction of oxygen in chromium. This is according to the concept of B.I. Kostetsky corresponds to the mechanism of formation of type 1 secondary structures on the friction surfaces, which are supersaturated solid solutions of the active component of the environment in the metal. A key property of oxygen-type surface structures, which is the initial stage of the chemical organization of elements in a solid state, is their surface localization, ultrafine structure, and the ability to minimize destruction and screen adhesion.

The results of studies developed by the nanostructured coatings of the $\mathrm{Cr}-\mathrm{Si}-\mathrm{B}-\mathrm{MgC} \mathrm{C}_{2}$ system, which have the necessary technical properties over the entire test range, are presented. At the same time, the possibility of increasing the antifriction of tribocontacts by using magnesium carbide in the composition of nanocoatings, which gives the formation of carbide graphite during friction, was proved theoretically and experimentally. It should be noted that the presence of magnesium carbide is an effective means of controlling wear and ensuring optimal anti-friction. Magnesium carbide through the structure influences the adaptation process during friction due to modified surface layers based on carbide graphite, which, in cooperative self-congruent with secondary structures, provide stable minimization of antifriction properties of coatings. Thus, the content of magnesium carbide in the coating, it is possible to regulate the processes of normal mechanochemical wear.

As can be seen from fig. 1 (curve 1), the change in the coefficient of friction is consistent with the established pattern of wear. The decrease in the friction coefficient and its stability with increasing load proves the good performance of the studied nanostructured coatings of the $\mathrm{Cr}-\mathrm{Si}-\mathrm{MgC} \mathrm{C}_{2}$ system. 


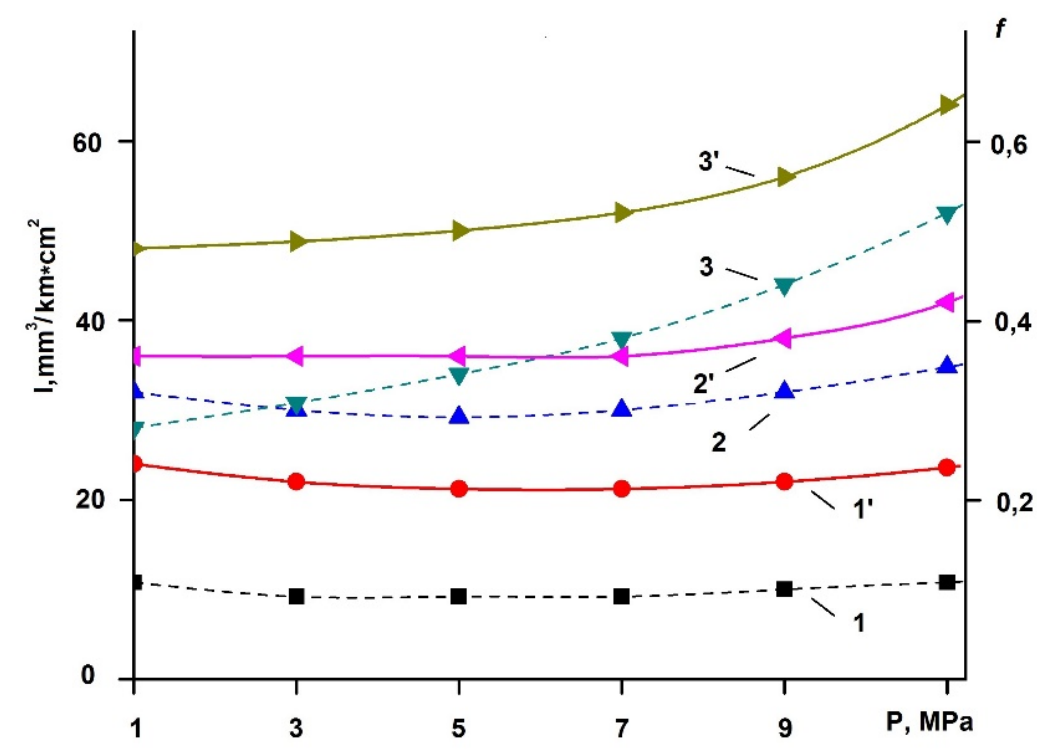

Fig. 3. Dependence of the wear rate $I(1,2,3)$ and the friction coefficient $f\left(1^{\prime}, 2^{\prime}, 3^{\prime}\right)$ on the load of the coatings Cr-Si-B-MgC 2 (1, 1'), WC-Co (2, 2'), Ni-Cr-Al-B (3, 3')

Also, VK15 coating (Fig. 1, curve 2) of tungsten-cobalt powder with high purity and uniformity has a fairly high wear resistance. Coating type VK15, as a traditional wear-resistant material, is used to protect against wear a high number of important details that are different in design and purpose. Under test conditions, at sliding speeds of more than $1.7 \mathrm{~m} / \mathrm{s}$, the temperature factor begins to influence the decrease in their resistance. High wear-resistant properties of VK coatings are stable up to operating temperature $540-580{ }^{\circ} \mathrm{C}$.

The result of the experiment (Fig. 1, curve 3) shows that for coatings based on nichrome doped with aluminum and boron, a monotonous increase in the wear rate with increasing sliding speed is seen from a value of $0.4 \mathrm{~m} / \mathrm{s}$. A study of the phase composition showed that the coating contains a solid solution based on nickel and dispersed mixtures of nickel aluminides ( $\mathrm{NiAl}, \mathrm{Ni}_{3} \mathrm{Al}$ ), chromium borides $\left(\mathrm{Cr}_{2} \mathrm{~B}, \mathrm{Cr}_{5} \mathrm{~B}_{3}, \mathrm{CrB}_{2}\right)$, as well as complex borides doped with nickel, such as $(\mathrm{Cr}, \mathrm{Ni})_{4} \mathrm{~B}_{5}$. The microhardness of the coating was $10600 \pm 500 \mathrm{MPa}$. The protective functions of secondary structures (heterophase oxide thin-film objects) with an increase in the sliding speed are the development of plastic deformation. As a result, the dynamic balance of activation and passivation processes is shifting. There is an increase in activation energy and the level of wear is changing qualitatively. According to the metallographic analysis, the friction surfaces studied at speeds of $2.0 \mathrm{~m} / \mathrm{s}$ have random flaw, furrow, which is typical for the initial period of development of seizure.

Thus, one of the most promising methods for increasing the tribological properties of coating materials is to control the composition and structural state of the surface, which is formed during friction with the formation of optimal structures.

The developed nanostructured coatings with magnesium carbide do not have expensive and scarce components, are ecologically-safe, have optimal antifriction properties and, by their operational capabilities, have the prospect of widespread use to produce competitive tribological products.

The most effective application of the developed nanostructured coatings is to improve the quality of operation of the slip pairs of technical systems, due to their use in hardening and the repair of movable mates of control mechanisms, hinges, guide surfaces, bushings, cams, footprint, levered parts, shafts, high-speed and heavily loaded nodes in which the use of traditional oils and greases is not suitable.

These studies prove the need to continue testing detonation nanostructured coatings of $\mathrm{Cr}$-Si-B-MgC to increase the antifriction of friction pairs under real operating conditions. But now it can be noted that their use will increase the resource and reduce repair costs when restoring worn parts.

The study of the mechanism of formation of a film of carbide polydisperse graphite contributes to the development of general methods for modifying the friction surface. It also makes it possible to control their structure and properties, allows us to develop technological processes for producing nanosized powder materials and spray them with coatings with high antifriction properties. These studies are the basis for the creation of new composite coatings with nanoscale components, which, in accordance with the above results, also affect the improvement of the friction properties and wear of moving pairs. 
The development of nanostructured coatings with carbide graphite according to the test results under various friction and wear conditions make it possible to develop tools of modern technology.

As monitoring of the international market has shown, the development and use of modern tribomaterials is mainly owned by foreign companies. With this in mind, when creating the nanoscale coatings indicated in the work, domestic raw materials were used.

Note that the developed nanostructured powder can be used to restore and harden worn parts by any technological methods that use powder materials.

The work performed did not rely on state financial and scientific-technical support; the results obtained were implemented by the authors.

\section{Conclusions}

1. Due to theoretical and experimental studies, the optimal structural-phase composition of the nanocomposite coatings of the $\mathrm{Cr}-\mathrm{Si}-\mathrm{B}-\mathrm{MgC}_{2}$ system, which does not contain scarce and expensive components, has been realized. The mechanisms of friction processes are established. High wear-resistant properties of the developed nanocoatings and stability of their quality are noted, in comparison with similar coatings of hard alloys based on tungsten carbide and doped nichrome.

2. By controlling the technological process of spraying composite nanocomponent powders, the necessary chemical composition and structure was formed, which modernizes the friction surface with an antifriction film of carbide graphite, prevents adhesive-molecular interaction and minimizes the properties of friction.

3. The physical mechanism is investigated and the main factors that determine thermodynamic graphitization are identified. When studying the properties and mechanisms that ensure the potential of coatings for passivation, it is noted that its implementation is carried out due to solid-phase chemical and diffusion processes of the formation of quasilaminar polydisperse surface layers based on graphite carbide and finely dispersed hardening phases from the components that make up the nanostructured coating.

4. The fundamental concepts of the formation and structure of antifriction surface structures based on polydisperse carbide graphite have been supplemented, which allowed the development of modern tribology tools.

\section{References}

1. Berman, D., Narayanan, B., Cherukara, M.J. and dr. Operando tribochemical formation of onion-like-carbon leads to macroscale superlubricity // Nat Commun. - 2018. - Vol. 9, No. 1164. - P. 1-9. https://doi.org/10.1038/s41467-018-03549-6

2. Wang, Hao \& Xie, Xuan \& Hua, Xijun \& Xu, Sheng \& Yin, Bifeng \& Qiu, Baijing. Analysis of the lubrication process with composition of solid lubricants of laser-modified sliding surfaces // Advances in Mechanical Engineering. - 2020. - No. 12. https://doi.org/10.1177/1687814020916078

3. Wu, Shiwen \& Tian, Siyu \& Menezes, Pradeep \& Xiong, Guoping. Carbon solid lubricants: role of different dimensions // The International Journal of Advanced Manufacturing Technology.-2020.-Vol. 8, - No. 107. - P. $3875-3895$. https://doi.org/10.1007/s00170-020-05297-8

4. Zhang, Tiantian \& Lan, Hao \& Yu, Shouquan \& Huang, Chuanbing \& Du, Lingzhong \& Zhang, Weigang. HighTemperature Solid Lubricant Coating by Plasma Spraying Using Metal-Metal Clad Powders. Journal of Thermal Spray Technology. - 2017. - No. 26. https://doi.org/10.1007/s11666-017-0591-0

5. Okovity, V.A., Panteleenko, F.I., Okovity, V.V., Astashinsky, V.M. Production of Composite Ceramic Material for Thermal Spraying // Science and Technology. - 2017. - No. 3. - P. 181-188.

6. Bolsunovskaya, T.A., Efimochkin, I.Yu., Sevostyanov, N.V. The influence of the brand of graphite as a solid lubricant on the tribotechnical properties of a metal composite material // Proceedings of VIAM. - 2018. - Vol. 67, - No. 7. - P. 69-77.

7. Patent № 119621 of Ukraine. Antifriction nanomaterial with magnesium carbide. Publ. 07.10.2019, Bull. №13 / Babak V.P., Shchepetov V.V, Suprun T.T, Bilchuk Ye.Yu.

8. Babak, V.P., Shchepetov, V.V., \& Harchenko, S.D. Antifriction Nanocomposite Coatings that Contain Magnesium Carbide // Journal of Friction and Wear, - 2019. - Vol. 6, No.40. - P. 593-598. https://doi.org/10.3103/S1068366619060035

9. Method of production crystalline nanopowders; Publ. 25.04.2017, Bull. №8 / Babak V.P., Shchepetov V.V., Astakhov E.A., Nedayiborsch S.D. Patent of Ukraine № 115482.

10. Dragobetskii, V.V., Shapoval, A.A., Mospan, D.V., Trotsko, O.V., Lotous, V.V. Excavator bucket teeth strengthening using a plastic explosive deformation // Metallurgical and Mining Industry, 2015. - No. 4. - P. 363-368.

11. Korniyenko, B.Y., Osipa, L.V. Identification of the granulation process in the fluidized bed// ARPN Journal of Engineering and Applied Sciences. - Vol. 13, - No. 14. - 2018. - P. 4365-4370. 


\title{
Износостойкость самосмазывающих нанокомпозиционных покрытий за счет образования карбидного графита
}

\author{
В. П. Бабак, В. В. Щепетов, С. Д. Харченко
}

\begin{abstract}
Аннотация. Приведены результаты исследования характеристик трения и изнашивания разработанных самосмазываюшихся детонаиионных нанокомпозииионных покрытий, содержаших $\mathrm{Mg} C_{2}$, который при твердофазном разложении, обусловленном причинной взаимосвязью термических и механических флуктуаций, образует структурносвободный $\alpha$-графит, создающий поверхностный антифрикиионный слой, минимизируюший контактные параметры. Представлен состав и структура самосмазываюшихся покрытий, которые показали высокие износостойкие характеристики во всём нагрузочно-скоростном диапазоне, моделирующим работу узла трения в реальных условиях. Отмечено, что средствами регулирования износа и обеспечения высокой работоспособности является наличие, как тонкопленочного слоя графита, так и образование тонко-дисперсных вторичных структур, обеспечивающих модифищирование поверхности трения и экранирующие недопустимые процессы пластической деформачии.
\end{abstract}

Ключевые слова: трение, износ, вторичные структуры, антифрикционный слой.

\section{Зносостійкість самозмащувальної нанокомпозиційних покриттів за рахунок утворення карбідного графіту}

\section{В. П. Бабак, В. В. Щепетов, С. Д. Харченко}

\begin{abstract}
Аннотация. Наведено результати дослідження характеристик тертя $i$ зношування розроблених самозмамувальних детонаційних нанокомпозиційних покриття, які мають $\mathrm{MgC}_{2}$, який при твердофазном розкладанні, обумовленому причинного взаємозв'язком термічних $і$ механічних флуктуачій, утворює структурно-вільний $\alpha$-графіт, щуо створює поверхневий антифрикиійний шар, що мінімізуе контактні параметри. Представлений склад $i$ структура самозмащувальних покриттів, які показали високі зносостійкі характеристики в усьому нагрузочно-швидкісному діапазоні, що моделює роботу вузла тертя в реальних умовах. Відзначено, що засобами регулювання зносу $і$ забезпечення високоі працездатності є наявність, як тонкопленочного шару графіту, так і утворення тонко-дисперсних вторинних структур, що забезпечують модифікування поверхні тертя і екранують неприпустимі прочеси пластичної деформації.
\end{abstract}

Ключові слова: тертя, знос, вторинні конструкції, антифрикційний шар.

\section{References}

1. Berman, D., Narayanan, B., Cherukara, M.J. and dr. (2018), "Operando tribochemical formation of onion-like-carbon leads to macroscale superlubricity", Nat Commun, vol. 9, no. 1164, pp. 1-9. https://doi.org/10.1038/s41467-018-03549-6

2. Wang, Hao, Xie, Xuan, Hua, Xijun, Xu, Sheng, Yin, Bifeng and Qiu, Baijing (2020), "Analysis of the lubrication process with composition of solid lubricants of laser-modified sliding surfaces", Advances in Mechanical Engineering, no. 12. https://doi.org/10.1177/1687814020916078

3. Wu, Shiwen, Tian, Siyu, Menezes, Pradeep L and Xiong, Guoping (2020), "Carbon solid lubricants: role of different dimensions”, The International Journal of Advanced Manufacturing Technology, vol. 8, no. 107. pp. 3875-3895. https://doi.org/10.1007/s00170-020-05297-8

4. Zhang, Tiantian, Lan, Hao, Yu, Shouquan, Huang, Chuanbing, Du, Lingzhong and Zhang, Weigang (2017), "HighTemperature Solid Lubricant Coating by Plasma Spraying Using Metal-Metal Clad Powders", Journal of Thermal Spray Technology, no. 26. https://doi.org/10.1007/s11666-017-0591-0

5. Okovity, V.A., Panteleenko, F.I., Okovity, V.V. and Astashinsky, V.M. (2017), "Production of Composite Ceramic Material for Thermal Spraying", Science and Technology, no. 3, pp. 181-188.

6. Bolsunovskaya, T.A., Efimochkin, I.Yu. and Sevostyanov, N.V. (2018), "The influence of the brand of graphite as a solid lubricant on the tribotechnical properties of a metal composite material", Proceedings of VIAM, vol. 67, no. 7, pp. 69-77.

7. Babak, V.P., Shchepetov, V.V, Suprun, T.T. and Bilchuk, Ye.Yu. (2019), Antifriction nanomaterial with magnesium carbide, Publ. 07.10.2019, Bull. №13, Ukraine, Patent № 119621.

8. Babak, V.P., Shchepetov, V.V. and Harchenko, S.D. (2019), "Antifriction Nanocomposite Coatings that Contain Magnesium Carbide", Journal of Friction and Wear, vol. 6, no. 40, pp. 593-598. https://doi.org/10.3103/S1068366619060035

9. Babak, V.P., Shchepetov, V.V., Astakhov, E.A. and Nedayiborsch, S.D. (2017), Method of production crystalline nanopowders, Publ. 25.04.2017, Bull. №8, Ukraine, Patent № 115482.

10. Dragobetskii, V.V., Shapoval, A.A., Mospan, D.V., Trotsko, O.V. and Lotous, V.V. (2015), "Excavator bucket teeth strengthening using a plastic explosive deformation", Metallurgical and Mining Industry, no. 4, pp. 363-368.

11. Korniyenko, B.Y. and Osipa, L.V. (2018), "Identification of the granulation process in the fluidized bed", ARPN Journal of Engineering and Applied Sciences, vol. 13, no. 14, pp. 4365-4370. 